\title{
Water transmission properties of a sandy loam soil under different tillage practices in Maiduguri, Nigeria.
}

\author{
${ }^{1}$ Sauwa, M.M., ${ }^{2}$ Chiroma, A.M., ${ }^{2}$ Waniyo, U.U., ${ }^{2}$ Ngala, A.L. and ${ }^{1}$ Danmowa, N.M. \\ ${ }^{1}$ Department of Soil Science and Agricultural Engineering, Faculty of Agriculture, Usmanu \\ Danfodiyo University, PMB 2346, Sokoto, Nigeria. \\ ${ }^{2}$ Department of Soil Science, Faculty of Agriculture, University of Maiduguri, Nigeria. \\ Corresponding author Email: mmsauwa4u@yahoo.com \\ ABSTRACT
}

\begin{abstract}
Knowledge of water transmission properties of soils could play a significant role in the choice of appropriate water management practices capable of alleviating production constraints of predominantly coarse textured soils of semi arid environments. The effect of 3 tillage systems (no-till :NT, reduced-till: RT and conventional tillage: CT) on water transmission properties of a sandy loam soil in Maiduguri was investigated after 9-15 years of management. Within the growing season of 2010 , saturated hydraulic conductivity $\left(\mathrm{K}_{\text {sat }}\right)$ was determined using undisturbed cores ( $10.8 \mathrm{~cm}$ in diameter and $12 \mathrm{~cm}$ in height) at surface $(0-15 \mathrm{~cm})$ and sub surface $(15-30 \mathrm{~cm})$ soil depths and infiltration rate determined using double ring infiltrometer method. The NT and RT treatments had higher $\mathrm{K}_{\text {sat }}$ values at both surface and sub surface soil depths (though the differences were not significant at $p \leq 0.05$ ) compared to the CT treatment. However, infiltration characteristics of the soil were significantly $(p \leq 0.05)$ greater for the NT and RT treatments relative to the CT treatment. The study revealed that, the NT and RT treatments better improved $\mathrm{K}_{\text {sat }}$ and infiltration characteristics of the soil relative to the CT treatment, and are therefore better management practices for improving water transmission properties of coarse textured soils in semi arid north eastern Nigeria.
\end{abstract}

Key words: Water transmission properties, Infiltration rate, saturated hydraulic conductivity, Infiltration characteristics

\section{INTRODUCTION}

The semi arid region of north-eastern Nigeria is predominantly characterized by coarse textured soils with low water retention and unstable structure. Rainfall in this region is erratic and often intensive, rendering soils susceptible to surface crusting, eventually decreasing water transmission through soils (Igboanugo and Badejo, 1998). Exposure of soil to high intensity rainfall also results in poor aggregation, reduced plant-water availability and erosion (Franzluebbers, 2002). From the foregoing, it becomes apparent that, practices that improve water transmission properties of soils could play a significant role in the choice of appropriate soil water management practices capable of alleviating production constraints of predominantly coarse textured soils of Maiduguri.

Infiltration rate $(\mathrm{IR})$ is the rate at which water enters the soil matrix through the surface. It governs the amount of water storage in soils, which is available to plants. It also influences the amount of runoff and erosion. Saturated hydraulic conductivity $\left(\mathrm{K}_{\text {sat }}\right)$ of a soil is its ability to conduct water after all pores are full of water (Lal and Shukla, 2004) implying that combined influence of IR and $\mathrm{K}_{\text {sat }}$ could significantly affect water regime of a soil. Folorunso (1986) maintained that IR determines how much of the water supplied to the soil surface (either through irrigation or rainfall event) actually enters the root zone or how much of it, if any, will runoff eventually accelerating soil erosion problems. With increasing global pressure on sustainable agriculture and environmental quality, knowledge of soil infiltration rate and $\mathrm{K}_{\text {sat }}$ becomes a prerequisite for efficient soil and water management.

Several workers have studied tillage effects on soil hydraulic properties, particularly water transmission properties (Benjamin, 1993; Singh et al., 1995; Azooz and Arshad, 1996; Jabro et al., 2008). However, results obtained are not consistent across soils and climates. Benjamin (1993) in lowa and Ohio found that, a no-till system (NT) had as great or greater $\mathrm{K}_{\text {sat }}$ as both moldboard plough (MP) and chisel plough 
(CP). This he attributed to greater pore continuity or flow through a very few large pores. Strudley et al. (2008) maintained that, $\mathrm{K}_{\text {sat }}$ and early intake rates into dry soils are affected by the presence of connected macropores, which can result from biological activities. Earthworm channels and other biopores had been reported to act as important conduits for movement of water through soil profile (Kladivko et al., 1986). However, Mielke and Wilhelm (1998) reported lower $\mathrm{K}_{\text {sat }}$ in the NT treatment compared to CT and sub-till treatments, while Jabro et al. (2008) observed no significant differences in $\mathrm{K}_{\text {sat }}$ between NT and some conventional systems on sandy loam soils after longer period of tillage imposition.

On the other hand, Barzeger et al. (2004) found greater IR in the CT compared to the NT and RT systems, and attributed this to the loosening effect of tillage implements used in the CT treatment. Conversely, in a study by Arshad et al. (1999) in Canada, NT treatment had greater steady ponded infiltration compared to the CT treatment despite negligible differences in bulk density $(\mathrm{Bd})$ observed. Similarly, Sauer et al. (1990) reported no-till soils having equal to or greater ponded infiltration compared to tilled soils despite greater $\mathrm{Bd}$ and lower total porosity (TP) of the no-till soils. Sauer et al. (1990) concluded that, a more stable structure in the
NT soils and an increased number of continuous earthworm channels connected to the surface might have contributed to the greater ponded infiltration of the NT soils. Generally, the inconsistencies characterizing results of tillage effects on soil hydraulic properties ( particularly water transmission properties ), suggests the need for more research in many regions of the world, for better understanding of tillage effects on hydraulic properties of soils.

The objective of the study was to evaluate the effect of different tillage systems on saturated hydraulic conductivity and infiltration characteristics of the soil.

\section{MATERIALS AND METHOD}

The Study Area: The study was carried out in Maiduguri, north east Nigeria. Climate of Maiduguri is semi arid with long-term mean annual rainfall (19611990) of $553 \mathrm{~mm}$. Rainfall distribution is unimodal, starting on the average in Mid June and las ting until the end of September (Grema and Hess, 19 94). Five sites were used for the study. The sites were selected based on their land use history. Soils of the study area are Sandy loam (Table 3) having parent material of Aeolian sand. GPR equipment (12 channel GPS etrex, courtesy GARMIN Corporation 1999-2002) was used in determining coordinates of the sites.

Table 2. Mean weight diameter of wet aggregates (MWDW) as affected by tillage systems

Tillage systems (\% remaining of oven dry sample initially added)

\begin{tabular}{cccccc}
\hline $\begin{array}{c}\text { Sampling depth } \\
(\mathbf{c m})\end{array}$ & $\begin{array}{c}\text { Aggregate Diameter } \\
(\mathbf{m m})\end{array}$ & $\mathbf{N T}$ & $\mathbf{R T}$ & $\mathbf{C T}$ & LSD(0.05) \\
& $>2$ & 2.510 & 2.410 & 1.560 & 0.278 \\
& $1-2$ & 9.942 & 9.982 & 7.324 & 1.549 \\
$0-15$ & $0.5-1$ & 9.692 & 9.410 & 7.416 & 1.250 \\
& $0.25-0.5$ & 6.190 & 5.020 & 5.390 & NS \\
& $<0.25$ & 71.666 & 73.178 & 78.310 & 2.682 \\
$15-30$ & $>2$ & 2.182 & 2.414 & 0.738 & 0.724 \\
& $1-2$ & 11.192 & 8.588 & 6.490 & 1.054 \\
& $0.5-1$ & 9.282 & 7.664 & 7.592 & 0.633 \\
& $0.25-0.5$ & 3.842 & 4.720 & 3.090 & 0.940 \\
& $<0.25$ & 73.502 & 76.614 & 82.090 & 1.147
\end{tabular}

NT-no till, RT-reduce till, CT-Conventional tillage

${ }^{2} N S$ - not significant at $p \leq 0.05$ 
Agric. Biol. J. N. Am., 2013, 4(3): 227-234

Treatments and Experimental design: The experiment was carried out using randomized complete block design (RCBD) with three treatments and five replications, and Statistix 8.0 (version 2005) analytical software was used in analyzing data obtained. Three tillage practices namely no tillage (NT), reduce tillage (RT) and conventional tillage (CT) were evaluated on each site. The location and and use history of the sites and tillage treatments eva luated is as follows:

SITE1: University of Maiduguri Teaching and Resear ch Farm (11 $\left.{ }^{\circ} 54^{\prime} \mathrm{N}, 13^{\circ} 5^{\prime} \mathrm{E}\right)$.

An uncultivated land (left fallow) for a period of 9-15 years was sampled in this site. The dominant plant species in this area are Andropogon gayanum, Cenchrus biflorus, and scattered Azadirachta indica trees. Adjacent to this field, a conventionally tilled plot continuously sown to groundnut and millet for about 9-15 years and a reduced-till plot continuously sown to groundnut and cowpea for a period of 9-15 years were also sampled. Tillage practices in the cultivated fields involved 1-2 tractor harrow passes and hand hoe cultivation per season for conventional tillage (CT) and reduced tillage (RT) treatments respectively. Further, NPK and Phosphatic fertilizers are commonly applied by farmers.

SITE 2: Livestock Farm, University of Maiduguri $\left(11^{\circ} 47.6^{\prime} \mathrm{N}, 13^{\circ} 12.5^{\prime} \mathrm{E}\right)$.

In this site, an uncultivated land left fallow for a period of 9-15 years and an adjacent conventionally tilled plot continuously sown to Maize and Cowpea for about $9-15$ years were sampled. A nearby reducedtill plot sown to Groundnut and Cowpea for a period of 9-15 years was also sampled. The Dominant plant species in this area are Senna obtusfolia, Achyranthes asper L., and scattered Balanities aegyptiaca trees. Tillage practices performed in the cultivated fields were same as those in site 1 .

SITE3: Kwayam Village, off University of Mai duguri $\left(11^{\circ} 47.9^{\prime} \mathrm{N}, 13^{\circ} 12.6^{\prime} \mathrm{E}\right)$.

At this site, uncultivated land left fallow for 9-15 years and an adjacent reduced- till plot sown to Millet and Cowpea for about 9-15 years were sampled. Adjacent to the reduced- till plot, a conventionally tilled plot continuously sown to Maize and Cowpea for 9-15 years was also sampled. The dominant plant species in this area are Cenchrus biflorus, Imperata cylindrica, and scattered Piliostigma reticulatum and Faidherbia albida trees. Tillage practices in the cultivated plots were same as those in site 1.
SITE 4: Old Malumbrari Primary School, Maiduguri $\left(11^{\circ} 47^{\prime} \mathrm{N}, 13^{\circ} 12.7^{\prime} \mathrm{E}\right)$.

In site 4, a soil uncultivated (left fallow) for about 9-15 years and a conventionally tilled plot adjacent to the uncultivated plot continuously sown to Groundnut and Cowpea for about 9-15 years were sampled. Adjacent to the conventional plot, a reduced- till plot continuously sown to Groundnut and Cowpea for 915 years was also sampled. The Dominant plant species in this area are Senna obtusfolia, Achyranthes asper L., Zizuphus mauritiana and Balanities aegyptiaca trees. The same tillage practice $\mathrm{s}$ were carried out as in site 1 .

SITE 5: University of Maiduguri Commercial Farm (11 '47.61'N,13⒔04'E ).

At this site, a field uncultivated (left fallow) for 9-15 years was sampled. Adjacent to this plot, conventionally tilled plot continuously sown to Millet and Cowpea for about 9-15 years and a reduced- till plot continuously sown to Millet and Cowpea for 9-15 years were also sampled. The dominant plant species in this area are Cenchrus biflorus, Achyranthes asper L., Senna obtusfolia, and scattered Balanities aegyptiaca trees. The same tillage practices for the cultivated plots in site 1 were also carried out in this site.

The five selected sites were within close proximity of one another, and within each selected site, treatment plots are located within 40-60 m of one another and had similar parent material (Aeolian sand) and textural composition (Table 3). During the growing season of 2010, triplicate undisturbed core samples (10.8 cm in diameter and $12 \mathrm{~cm}$ height) were obtained at surface $(0-15 \mathrm{~cm})$ and sub surface $(15-30$ $\mathrm{cm})$ soil layers for the determination of saturated hydraulic conductivity $\left(\mathrm{K}_{\text {sat }}\right)$ using the falling head permeameter method of Klute (1986). While infiltration rate (IR) of the soil was determined using the double-ring infiltrometer method of Bertrand (1965). The inner and outer rings were $30 \mathrm{~cm}$ and 60 $\mathrm{cm}$ in diameter and $35 \mathrm{~cm}$ in height respectively. Both the inner and outer rings were inserted into the soil at $10 \mathrm{~cm}$ depth. The sides of the rings were carefully packed with sand to minimize edge effects on measured infiltration rates. A plastic meter rule was inserted inside the inner ring to measure infiltration rate of the soil. Measurements were made in triplicate and their average calculated to represent infiltration rate and $\mathrm{K}_{\text {sat }}$ of the soil. The mean weight diameter of water stable aggregates (MWDW) was determined using method of Kemper (1965) which involved 
presoaking the soil sample (previously sieved through $4 \mathrm{~mm}$ sieve) for 10 minutes on topmost nest of sieves of diameter 2, $1,0.5$, and $0.25 \mathrm{~mm}$, then vertically oscillating them for 20 minutes at the rate of 1 oscillation per second, oven drying the resistant aggregates and recording their masses.

Macro aggregates of wet (MAW) and dry (MAD) aggregates were determined as weight of aggregates $>0.25 \mathrm{~mm}$ in diameter, while dispersion ratio (DR) and water stability index (WSI) were deter mined by the following methods :

Dispersion ratio (DR): Dispersion ratio was computed as $\mathrm{DR}=(\mathrm{A} / \mathrm{B}) \times 100$. Where $A=$ Percent silt + clay in water-dispersed sample, and $B=$ Percent silt + clay in calgon-dispersed sample ((Middleton, 1930). Water- stability index (WSI \%): Water stability index was computed as $100(1-A / B)$. Where $A$ is percentage of aggregates which passed a 0.20 $\mathrm{mm}$ sieve in 5 minutes after shaking at the rate of 60 oscillations per minute at room temperature and $B$ is the percentage that passed after 60 minutes under the same conditions (Malquori and Cecconi, 1962). Organic carbon (OC) content of the soil was determined using wet oxidation method of Walkley and Black (1934). One profile pit was dug in each treatment plot to observe profile characteristics.

\section{RESULTS AND DISCUSSION}

Saturated Hydraulic Conductivity (Ksat): Significant $(p \leq 0.05)$ treatment differences in $\mathrm{K}_{\text {sat }}$ of the soil due to tillage treatments were not observed at both surface $(0-15 \mathrm{~cm})$ and sub surface $(15-30 \mathrm{~cm})$ soil depths (Fig. 1) which is in agreement with the findings of previous study carried out in the area (Chiroma et al. 2006) and elsewhere (Jabro et al. 2008). However, $\mathrm{K}_{\text {sat }}$ at both surface (5.34 and 5.12 $\left.\mathrm{cm} \mathrm{h}^{-1}\right)$ and sub surface $\left(5.42\right.$ and $\left.5.38 \mathrm{~cm} \mathrm{~h}^{-1}\right)$ soil depths respectively were higher for the conservation tillage systems (NT and RT) compared to the CT treatment $\left(4.80\right.$ and $4.94 \mathrm{~cm} \mathrm{~h}^{-1}$ for surface and sub surface soil depths respectively) despite greater $\mathrm{Bd}$ and lower TP of these treatments (data not shown). Similar observations were made by Singh et al. (1995). The $\mathrm{K}_{\text {sat }}$ values observed in this study are within the range of $\mathrm{K}_{\text {sat }}$ values $\left(5-69 \mathrm{~mm} \mathrm{~h}^{-1}\right.$ ) reported by Daragmeh et al. (2008) due to tillage in sandy loam. Apparently, $\mathrm{K}_{\text {sat }}$ decreased with increasing intensity of tillage. Fair correlation between $\mathrm{K}_{\text {sat }}$ and organic carbon (OC) content of the soil was observed, at both surface $(r=0.62)$ and sub surface $(r=0.58)$ soil depths as well as some aggregate stability indices at surface soil depth (Table 1). The regression equation relating $\mathrm{K}_{\text {sat }}$ and
OC at both surface and sub surface depths are presented as:

$$
\begin{aligned}
& \mathrm{K}_{\text {sat }}(0-15 \mathrm{~cm})=3.74+5.32 \mathrm{OC} ; \mathrm{r}^{2}=0.99 \\
& \text {.................... } 1 \\
& \mathrm{~K}_{\mathrm{sat}}(15-30 \mathrm{~cm})_{2}=3.52+10.98 \mathrm{OC} ; \mathrm{r}^{2}=0.96
\end{aligned}
$$

The above equations showed that for every unit increase in OC, there is a corresponding 5.32 and 10.98 unit increases in $\mathrm{K}_{\text {sat }}$ for the surface and sub surface soil depths respectively. Generally, $\mathrm{K}_{\text {sat }}$ values were similar for both surface and sub surface soil depths (Fig. 1). Apparently, loss of organic matter (expressed as OC) and aggregate stability: reflected by lower macro aggregates i.e aggregates $>0.25 \mathrm{~mm}$ (Table 2) partly explains the decreased $\mathrm{K}_{\text {sat }}$ in the CT treatment. Further, limited soil disturbance in the NT and RT treatments kept pore structure continuous leading to greater $\mathrm{K}_{\text {sat }}$ of these treatments compared to the CT treatment. In addition, retention of greater organic matter for both surface and sub surface soil depths by the NT and RT treatments led to slight improvement in the $\mathrm{K}_{\text {sat }}$ of the soil. This improvement might be related to better soil structure as evident by relatively greater proportions of macro aggregates as surface stable aggregates in the NT and RT treatments, than in CT treatment (Table 2) thus rendering them more resistant to slaking (when in contact with water) relative to the CT treatment. Earlier workers attributed the relatively higher $\mathrm{K}_{\text {sat }}$ values of conservation tillage systems relative to the conventional tillage system to greater OC content (Chiroma et al., 2006); better pore continuity (Singh et al., 1995; Azooz and Arshad, 2001; Jabro et al., 2008).

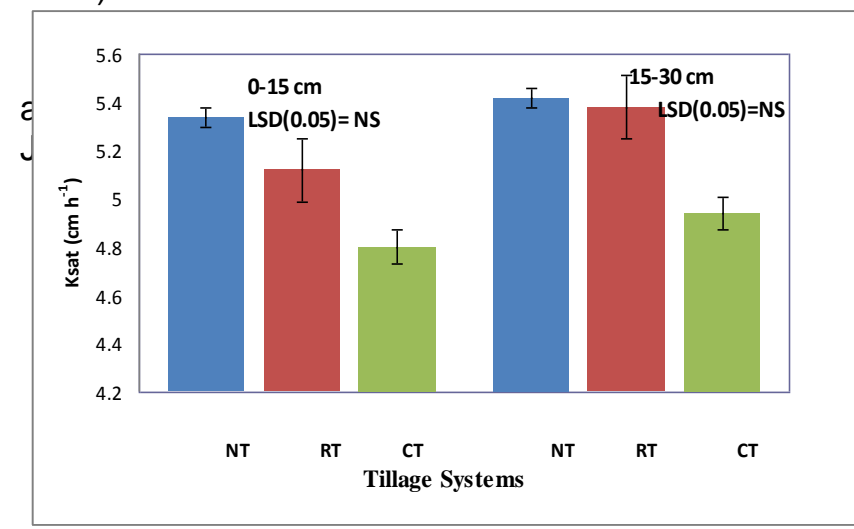

Fig 1. Effect of tillage systems on mean saturated hydraulic conductivity $\left(\mathrm{K}_{\text {sat }}\right)$ of the soil at 0-15 and 15$30 \mathrm{~cm}$ soil depths (bars indicate standard error) 
Infiltration Characteristics: Infiltration characteristics of the soil (infiltration rate, cumulative infiltration and steady state infiltration) as a function of time (cumulative time) were significantly $(p \leq 0.05)$ affected by tillage systems (Fig. 2). The initial infiltration rate (IR) of the soil was significantly different among tillage treatments. The NT and RT treatments recorded greater initial infiltration rates $\left(43.2\right.$ and $\left.43.4 \mathrm{~cm} \mathrm{~h}^{-1}\right)$ respectively for the first 5 minutes, compared to the CT treatment $\left(36.5 \mathrm{~cm} \mathrm{~h}^{-1}\right)$ Fig. 2. The same trend in changes in infiltration rate was observed over the period of measurement ( 3 hours). Similarly, the cumulative infiltration $(\mathrm{cm})$ after 3 hours was also greater for the NT and RT treatments (52.10 and $47.48 \mathrm{~cm}$ ) compared to the CT treatment $(29.20 \mathrm{~cm})$ Fig. 2. In addition, the steady state infiltration rate was also greater for the NT and RT treatments $(9$ and $7 \mathrm{~cm}$ $\left.\mathrm{h}^{-1}\right)$ relative to the CT treatment $(5.8 \mathrm{~cm} \mathrm{~h}-1)$ Fig. 2 . The CT treatment reached its steady state infiltration rate faster ( $120 \mathrm{~min}$ ) compared to the NT and RT treatments ( 150 minutes) respectively ( Fig. 2). This could be due to relatively smaller pore heterogeneity and less stable aggregates (Table 2) in the CT treatment compared to the NT and RT treatments (Singh et al., 1995). Escavation of profiles displayed abundant rotting roots and biochannels in the NT and RT treatments which served as important conduits for movement of water through the soils (Kladivko et al.1986; Singh et al., 1995) despite greater Bd of these treatments relative to the CT treatment (data not shown).

Further, less soil disturbance in the NT and RT treatments, also kept pore structure continuous which aids greater water transmission through the soil (Singh et al.,1995; Azooz and Arshad,1996;Jabro et al.,2008) . Conversely, less stable aggregates in the CT treatment (Table 2 ) upon intense rainfall event (which are common in the semi arid tropic) clog soil pores through slaking of aggregates leading to decrease in water transmission through the soil( Pikul and Aase ,1995;Mbagwu and Auerswald, 1999 ). Therefore, the greater water transmission in the NT and RT treatments could be attributed to greater aggregate strength, better pore continuity and presence of biochannels. Decreased water transmission through soils, reflected by decreased $\mathrm{K}_{\text {sat }}$ and infiltration rate has detrimental effects on soil productivity, as it increases the volume of runoff, accelerate soil erosion problems, thereby affecting water economy of crop plants (Folorunso, 1986; Franzluebbers,2002).

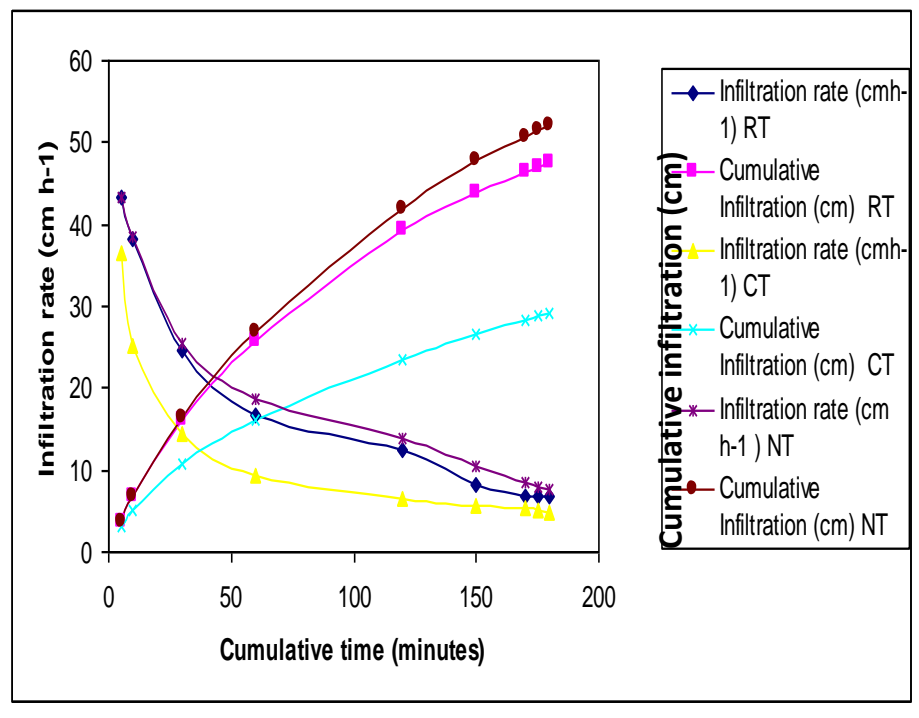

Fig 2. Effect of tillage systems on infiltration characteristics of the soil

Table 1. Pearson correlation between $\mathrm{K}_{\text {sat }}, \mathrm{OC}$ and some aggregate stability indices of the soil at 0-15 cm and $15-30 \mathrm{~cm}$ soil depth

\begin{tabular}{cccccc}
\hline $\begin{array}{c}\text { Soil } \\
\text { depth }\end{array}$ & MAD & MAW & DR & WSI & OC \\
\hline $0-15 \mathrm{~cm}$ & $0.15 \mathrm{~ns}$ & 0.51 & 0.56 & $0.34 \mathrm{~ns}$ & $0.62^{* *}$ \\
$15-30 \mathrm{~cm}$ & $0.44 \mathrm{~ns}$ & $0.43 \mathrm{~ns}$ & $0.20 \mathrm{~ns}$ & $0.16 \mathrm{~ns}$ & $0.58^{*}$ \\
\hline
\end{tabular}

1- OC-organic carbon, MAW- wet macro aggregate, MAD- dry macro aggregate, DR- dispersion ratio, WSI- water stability index $2-{ }^{*},{ }^{* *}$, means significant at $5 \%$, and $1 \%$ level of probability respectively 
Agric. Biol. J. N. Am., 2013, 4(3): 227-234

Table 3: Percentage sand, silt and clay contents of individual treatment plots for surface $\mathbf{0 - 1 5} \mathrm{cm}$ soil layer

\begin{tabular}{ccccc}
\hline Treatments & (\% sand) & (\% silt) & (\% clay) & Textural class \\
\hline NT 0 -15 cm & 72.1 & 18.2 & 9.7 & Sandy loam \\
1 & 67.1 & 20.7 & 12.2 & Sandy loam \\
2 & 69.6 & 20.7 & 9.7 & Sandy loam \\
3 & 69.6 & 18.2 & 12.2 & Sandy loam \\
4 & 69.6 & 20.7 & 9.7 & Sandy loam \\
5 & & & 12.2 & Sandy loam \\
RT & 69.6 & 18.2 & 7.2 & Sandy loam \\
1 & 72.1 & 20.7 & 9.7 & Sandy loam \\
2 & 69.6 & 20.7 & 12.2 & Sandy loam \\
3 & 69.6 & 18.2 & 12.2 & Sandy loam \\
4 & 67.1 & 20.7 & & \\
5 & & & 12.2 & Sandy loam \\
CT & 72.1 & 15.7 & 9.7 & Sandy loam \\
1 & 72.1 & 18.2 & 12.2 & Sandy loam \\
2 & 69.6 & 18.2 & 9.7 & Sandy loam \\
3 & 67.1 & 23.2 & 12.2 & Sandy loam \\
4 & 69.6 & 18.2 & & \\
\hline
\end{tabular}

\section{CONCLUSIONS}

Tillage systems significantly $(p \leq 0.05)$ affected infiltration characteristics of the soil but not $\mathrm{K}_{\text {sat }}$. However, the NT and RT treatments showed better $\mathrm{K}_{\text {sat, }}$ infiltration rate, cumulative infiltration and steady state infiltration rates compared to the CT treatment. This implied that, the NT and RT treatments better improved water transmission properties of the soil relative to the CT treatment, and are therefore, better soil water management options for coarse textured soils of semi arid northeastern Nigeria.

\section{REFERENCES}

Arshad, M.A., Franzluebbers, A.J. and Azooz, R.H. 1999. Components of surface soil structure under conventional and no-tillage in northwestern Canada. Soil Tillage Res. 53(1):41- 47.

Azooz, R.H. and Arshad, M.A. 1996. Soil infiltration and hydraulic conductivity under long term notillage and conventional tillage systems. Can. J. Soil Sci. 76 : $143-152$.

Azooz, R.H. and Arshad, M.A. 2001. Soil water drying and recharge rates as affected by tillage under continuous barley and barley-canola cropping systems in northwestern Canada. Can. J. Soil Sci. $81(1): 45-52$.

Barzegar, A.R., Asoodar, M.A., Eftekhar, A.R. and Herbert, S.J. 2004. Tillage effects on soil physical properties and performance of irrigated wheat and Clover in semi arid region. J. Agron. 3(4): 237 -242.
Benjamin, J.G. 1993. Tillage effects on near-surface soil hydraulic properties. Soil Tillage Res. 26 (4): 277-288.

Bertrand, A.R. 1965. Rate of water intake in the field. In: Methods of soil Analysis. Am. Soc. Agron.monograph 9.pp $197-208$.

Chiroma, A.M., Foloronso, O.A., Alhassan, A.B. 2006. The effects of land configuration and wood- shavings mulch on the properties of a sandy loam soil in Northeast Nigeria. 2. Changes in physical properties. Tropicultura 24(1) : 33-38.

Daragmeh, O.A., Jensen, J.R. and Petersen, C.T. 2008. Near saturated hydraulic properties in the surface layer of a sandy loam soil under conventional and reduced tillage. Soil Sci. Soc. Am. J. 72(6): 1728-1737.

Folorunso, O.A. 1986. Distribution of field-measured steady-state infiltration rate for a Borno State soil. Annals of Borno 3:193-204.

Franzluebbers, A.J. 2002. Water infiltration and soil structure related to organic matter and its stratification with depth. Soli Tillage Res. 66 :197-205.

Grema A.K. and Hess, T.M. 1994. The impact of changing rainfall patterns on the efficiency of rainfall utilization in pearl millet - cowpea intercropping systems in north east Nigeria. Aspects of Applied Biology 38:231 - 238.

Igboanugo, A.B.I. and Badejo,M.A.1998. In: Badejo,M.A. andTogun,A.O.1998 (eds) Strategies and tactics of sustainable Agriculture in the tropics. College press, Ibadan. pp149-167. 
Jabro, J.D., Sainju, U.M., Stevens, W.B., Lenssen, A.W., Evans, R.G. 2008. Long-term tillage frequency effects on dryland soil physical and hydraulic properties. Inter. Soil Conserv. Org. Conf. Proc. may 15-23, 2008, Budapest, Hungary. pp 1-4.

Kemper,W.D. 1965. Aggregate stability. In: Methods of soil Analysis part 2(ed. C.A.Black). Society of Agronomy, Madison. Pp 511-519.

Kladivko, E.J., MacKay, A.D., Bradford, J.M. 1986. Earthworms as a factor in the reduction of soil crusting. Soil Sci. Soc. Am. J. 50: 191-196.

Klute, A.1986. Methods of soil Analysis, part 1. Physical and mineralogical properties. Agronomy monograph No.9. ASA, Madison, Wisconsin.

Lal, R. and Shukla, M.K. 2004. Principles of soil physics. Marcel Dekker Inc. NewYork. Pp 405- 411.

Malquori, A.R. and Cecconi, S. 1962. Determinazione Seriale del Terreno. Agrochimica 6. Pp 198-204.

Mbagwu, J.S.C. and Auerswald, K. 1999. Relationship of percolation stability of soil aggregates to land use, selected soil properties, structural indices and simulated rainfall erosion. Soil Tillage Res. 50: 197206.

Middleton, H.E. 1930. Properties of soils which influence soil erosion. United States Department of Agriculture Technical Bulletin Number 178.
Mielke, L.N. and Wilhelm, W.W. 1998. Comparisons of soil physical characteristics in long term tillage winter wheat fallow tillage experiments. Soil Tillage Res. 49:29-35

Pikul, J.L. and Aase, J.K. 1995. Infiltration and soil properties as affected by annual cropping in the Northern Great Plains. Journal Agron. 87(4): 654-662.

Sauer, T.J., Clothier, B.E. and Daniel, T.C. 1990. Surface measurements of the hydraulic character of tilled and untilled soil. Soil Tillage Res. 15: 359-369.

Singh, B., Chanasyk, D.S., McGill, W.B. 1995. Soil hydraulic properties of an orthic black chernozem under long-term tillage and residue management. Can. J. Soil Sci. 76: 63-71.

Statistix 8.0 2005. Version 2005, statistix for windows analytical Software, USA.

Strudley, M.W., Green, T.R. and Ascough, J.C. 2008. Tillage effects on soil hydraulic properties in space and time: State of the science. Soil Tillage Res. 99: 4 - 48.

Walkley, A. and Black, I.A. (1934). An examination of the degtjareff method of determining soil organic matter, and proposed modification of the chromic acid titration method. Soil Science $37: 29-38$. 